\title{
ПРОЕКТЫ ОРГАНИЗАЦИИ \\ РЕГУЛЯРНОГО ПАРОХОДНОГО СООБЩЕНИЯ НА АНГАРЕ (НАЧАЛО ХХ СТОЛЕТИЯ)
}

Автор статьи анализирует проекты по организации пароходного сообщения на Ангаре в начале XX в.

Ключевые слова: ангарское пароходство, освоение ангарского водного пути, история водного транспорта Восточной Сибири в начале XX в., хозяйственное освоение Приангарья в начале XX в.

\section{DRAFTS FOR ORGANIZATION OF REGULAR STEAMSHIP TRAFFIC ON THE ANGARA RIVER (THE BEGINNING OF THE XX CENTURY)}

The author analyzes the projects on the organization of steamship traffic on the Angara River in the early XX century.

Keywords: Angara shipping company, development of the Angara river waterway, history off water transportation in Eastern Siberia in the early XX century, economic development of the Baikal region in the early $\mathrm{XX}$ century.

В начале XX столетия вновь обсуждался вопрос о возможности установления срочного проходного сообщения в низовьях Ангары. Эта проблема была в центре внимания заседания, состоявшегося 26 июля 1908 г. под председательством енисейского вице - губернатора Н.П. Беломестного. К участию в заседании были приглашены известные на Енисее судовладельцы - Н.Н. Гадалов и Ф.К. Черепанова, а также красноярский городской голова - П.К. Гудков.

Участники собрания обратили внимание на тот фракт, что паровой фрлот, находящийся на Енисее, не пригоден для рейсирования по Ангаре, поскольку ее глубины и перекаты (до 2-х футов) не соответствуют судовой осадке казенных пароходов.

По Ангаре могут совершать плавание лишь особо приспособленные мелкосидящие пароходы (4 рейса в навигацию). Движение судов возможно на расстоянии 900 верст от ангарского устья до Шаманского порога. Было подчеркнуто, что пароходы не «могут иметь большую грузоподъемность, поскольку не будут принимать значительные грузовые потоки, а лишь буксировать барки, поднимающие не более 10 тыс. пудов». 
Считалось, что для срочного пароходства вполне достаточно иметь два парохода и две баржи, общей стоимостью приблизительно 255 тыс. р. Также потребуется «заведение цепей» длиной 5 тыс. саж. по цене 80 тыс. р. Таким образом, единовременные затраты на приобретение фрлота должны составить около 355 тыс. р. [1, л. 16].

Рассчитывали, что на содержание судов в навигацию достаточно около 78 тыс. р., а ежегодный расход по предприятию не будет превышать 118,5 тыс. р. Предварительные расчеты показывали, что первоначальный оборот грузов («сырые» продукты сельского хозяйства, продукция местных промыслов, грузы Акцизного ведомства) будет незначительным - 90 тыс. пудов, а «валовая доходная цифра» - около 18 тыс. р., поэтому ежегодная субсидия на поддержку срочных рейсов устанавливалась в 100 тыс. р. [1, л. 16].

Чтобы предприятие имело хотя бы незначительную прибыль предлагалось удвоить существующие грузовые тарифы («сейчас стоимость пуда хлеба по течению 1/100 к., а против течения - 1/50 к., остальные грузы - 15 к. с пуда по течению и 25 к. в обратном направлении»).

Перед открытием срочного пароходства необходимо обустроить фрарватер, устранить препятствия, затрудняющие движение судов, построить шлюзовые каналы у Шаманского и Падунского порогов. Работы могут быть выполнены в течение трех лет, а затраты на их проведение составят 15 млн р. В протоколе заседания отмечалось, что этот путь (от устья Ангары до Шаманского порога «... мог бы способствовать росту колонизации, развитию [сельского хозяйства], сбыту продуктов хозяйства и местных промыслов, обслуживать нужды Акцизного ведомства ... приисков Северной Енисейской тайги подвозкой хлебов и грузов» $[1$, л. 15].

Этот оптимистический вывод не разделял Н.Н. Гадалов, поэтому и не поставил свою подпись в итоговом протоколе, полагая, что «... нельзя писать о росте колонизации, пока не будет удостоверено, что край этот пригоден для массового заселения, а, если он окажется непригодным, то затрачивать такую массу казенных средств нецелесообразно, и, кроме того, это пароходство не может обслуживать прииски северной Енисейской тайги, так как она слишком удалена от Ангары» [1, л. 17].

Свое особое мнение (от 2 сентября 1908 г.) направил Н.П. Беломестному Ф.Г. Черепанов.

Судовладелец видел исключительную пользу установления срочного пароходства, считая, что этот транзитный путь соединить Край с Забайкальем и Иркутской губернией, что благотворно скажется на их экономическом развитии. Этот шаг важен и с внешнеполитической точки зрения, поскольку на случай возможного столкновения с Китаем и Японией будет существовать надежный транзитный путь для доставки военных грузов. 
Ф.Г. Черепанов полагал, что строительство гидротехнических сооружений на Ангаре необходимо и польза от них очевидна. Поскольку проект потребует крупных затрат, необходимо внимательно рассмотреть его и только тогда принять важное решение.

Проект остался не реализованным и не заинтересовал енисейских судовладельцев.

Годом раньше, 23 сентября 1907 г. ссыльнопоселенец деревни Алешкино Кежемской волости Енисейской губернии и уезда, в прошлом юрист-консультант обществ Китайско-Восточной и Московско-Казанской железных дорог А.И. Козлов, обратился генерал губернатору А.Н. Селиванову с прошением об организации пароходства на Ангаре.

Установление пароходства, по замечанию Козлова, необходимо хотя бы для того, чтобы местные жители имели «дешевый способ передвижения» и появилась возможность перевозить грузы первой необходимости по ценам более низким, чем существуют сейчас. «Так фунт сахара 25 к., ситец 22 к. и более, мука крупчатка 12-15 к., чай кирпичный самого низкого сорта 1 р. 80 к. за пачку, суконный товар в 2 раза превышает фабричную стоимость. Этот товар, если бы отправить из Енисейска на пароходе может продаваться по самой большой цене: фунт сахара 16 к., ситец - 9-13 к. аршин, мука крупчатка 5 копеек за фунт, чай кирпичный - 90 к. за пачку» [1, л. 1 об.].

В первую навигацию пароход сможет перевозить не более 100 тыс. пудов грузов «так как невозможность сбыта не развила хлебопашества, скотоводство не приспособило местных жителей к засолу мяса и рыбы, последние в Ангаре много...» [1, л. 1 об.].

Козлов просил местную администрацию выделить в распоряжение артели, состоящей из слесарей, машинистов, боцманов, матросов, техников мелкосидящий пароход для плавания по Ангаре и ежегодную субсидию 10 тыс. р. Предприниматель не сомневался в успехе предприятия и был уверен, что «государственные деньги» будут «возвращаться» по окончанию навигации, как и сам пароход «будет таков же как во время приема его в артель» [1, л. 1 об.].

В качестве примера подобной деятельности Козлов приводил работу корпорации моряков во Владивостоке, получавшей от правительства проходы и субсидию.

Генерал-губернатор Селиванов рассмотрел предложение 15 октября 1907 г. и наложил резолюцию: «Просителю отказать по неблагонадежности».

10 марта 1908 г. енисейский губернатор сообщил в Управление строительной дорожной частями, что «средств для гарантии казенного пароходства, как и сам Козлов, так его участники не имеют», а 5 апреля в Кежемское волостное правление поступило распоряжение уведомить Козлова об отклонении его ходатайства [1, л. 4]. 


\section{Список использованной литературы и источников}

1. Государственный архив Иркутской области. - Ф. 31 (Управление строительной и дорожной частями при Иркутском генерал-губернаторе). - Оп. 3. - Д. 393.

\section{Информация об авторе}

Гузенков Сергей Васильевич - кандидат исторических наук; e-mail: s-guzenkov@mail.ru

\section{Author}

Sergej V. Guzenkov — PhD in History; e-mail: s-guzenkov@mail.ru 